\title{
A NEW SULFATE-REDUCING BACTERIUM ISOLATED FROM ANTARCTICA
}

\author{
HIROSHI IIZUKA, HIROSHI OKAZAKI AND NAOSUKE SETO \\ Institute of Applied Microbiology, The University of Tokyo, Tokyo
}

(Received June 19, 1968)

\begin{abstract}
Determinative studies were carried out with an obligatory anaerobic spore-forming sulfate-reducing bacterium, strain No. 64, isolated from the SKARVS NES district in the East Antarctica. This sulfate-reducing bacterium belongs to the genus Desulfotomaculum differing from all of the known species of the genus in respect to glucose fermentation, gelatin liquefaction, optimum temperature for growth, and nutritional requirements. The strain was determined to be a new species of the genus Desulfotomaculum, $D$. antarcticum, IIZUKA et OKAZAKI nov. sp.
\end{abstract}

The presence of obligatory anaerobic sulfate-reducing bacteria in the Antarctica has already been reported in 1963 by BARGHOORN and NICHOLS (1) who studied the pyritic sediment of Kettle holes in the McMurdo Sound region. In the above investigation, they pointed out that the isolated bacteria belonged to the genus Desulfovibrio. However, further taxonomical investigations on these Desulfovibrio species have not been reported, and the presence of spore-forming species of sulfate-reducing bacteria, Desulfotomaculum species, has not been recorded either in the Antarctica. In the present investigations on the microflora of the Antarctic circle, a Desulfotomaculum species was found. I $\hat{\imath}$ did not fit into any hitherto known species in some properties. The results of determinative studies are described herein.

\section{MATERIALS AND METHODS}

Isolation of sulfate-reducing bacteria. At the SKARVS NES district $\left(69^{\circ} 30^{\prime} \mathrm{S}, 39^{\circ} 40^{\prime} \mathrm{E}\right)$, which is about $60 \mathrm{~km}$ southeast of SHOWA base, two pond water and seven mud samples (Fig. 1) were collected by Y. Honkawa during the Eighth Japanese Antarctic Research Expedition (1966-1967) and were kept in a frozen state until examined. The time interval between collection of the samples and isolation of the cultures was approximately 4 months. For the enrichment culture of sulfate-reducing bacteria, the following culture media were used: Postgate's medium (per liter); Na lactate, $3.0 \mathrm{~g}$; peptone, $2.0 \mathrm{~g}$, $\mathrm{MgSO}_{4} \cdot 7 \mathrm{H}_{2} \mathrm{O}, 2.0 \mathrm{~g}$; yeast extract, $0.5 \mathrm{~g} ; \mathrm{K}_{2} \mathrm{HPO}_{4}, 0.2 \mathrm{~g} ; \mathrm{FeSO}_{4} \cdot 7 \mathrm{H}_{2} \mathrm{O}, 0.2 \mathrm{~g}$; $\mathrm{Na}$ ascorbate, $0.1 \mathrm{~g} ; \mathrm{pH}$ 7.5. Sorokin's medium (per liter); Na lactate, $0.5 \mathrm{~g}$; 


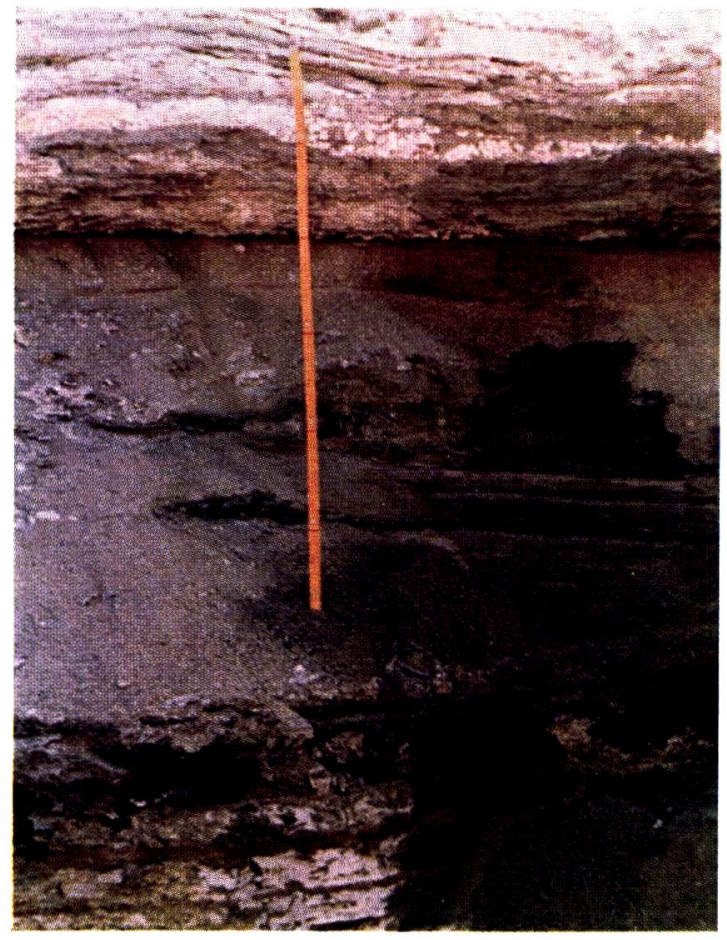

Fig. 1. The location where sulfate-reducing bacteria were discovered.

The white layer contains sodium sulfate and sodium carbonate. This place is located at the SKARVS NES district $\left(69^{\circ} 30^{\prime} \mathrm{S}\right.$, $\left.39^{\circ} 40^{\prime} \mathrm{E}\right)$.

$\mathrm{MgSO}_{4} \cdot 7 \mathrm{H}_{2} \mathrm{O}$, trace ; L-cystine, trace; $\mathrm{K}_{2} \mathrm{HPO}_{4}, 0.5 \mathrm{~g} ; \mathrm{CaSO}_{4} \cdot 2 \mathrm{H}_{2} \mathrm{O}, 0.5 \mathrm{~g} ; \mathrm{pH}$ 7.0. Starkey's medium (per liter); $\mathrm{Na}$ lactate, $3.0 \mathrm{~g} ; \mathrm{KH}_{2} \mathrm{PO}_{4}, 0.5 \mathrm{~g} ; \mathrm{NH}_{4} \mathrm{Cl}, 1.0$ $\mathrm{g} ; \mathrm{Na}_{2} \mathrm{SO}_{4}, 1.0 \mathrm{~g} ; \mathrm{MgSO}_{4} \cdot 7 \mathrm{H}_{2} \mathrm{O}, 2.0 \mathrm{~g}$; Mohr's salt, $0.5 \mathrm{~g} ; \mathrm{CaCl}_{2} \cdot 2 \mathrm{H}_{2} \mathrm{O}, 0.1 \mathrm{~g}$; yeast extract, $1.0 \mathrm{~g} ; \mathrm{pH}$ 7.5. Further, sodium chloride was added into each medium in two kinds of concentration, $0.5 \%$ and $2.5 \%$. Samples were added into $100-$ $\mathrm{ml}$ Erlenmeyer flasks containing $20 \mathrm{ml}$ each of these media and incubated in a desiccator containing $\mathrm{N}_{2}$ gas at $5^{\circ}, 10^{\circ}, 20^{\circ}$, and $30^{\circ}$ for 7 to 20 days.

Isolation and purification of sulfate-reducing bacteria from these enrichment cultures were performed by the tube culture method (2) or the plate culture method on the TSB-plus-salts agar medium (3) consisting of (per liter); tryp$15.0 \mathrm{~g}$; phytone, $5.0 \mathrm{~g}$; Na lactate, $4.0 \mathrm{~g}$; $\mathrm{MgSO}_{4} \cdot 7 \mathrm{H}_{2} \mathrm{O}, 2.0 \mathrm{~g}$; Mohr's salt, $0.5 \mathrm{~g}$; ticase, $\mathrm{NaCl}, 0.5$ or $25.0 \mathrm{~g}$; agar, $15.0 \mathrm{~g}$; pH 7.4.

Morphological characteristics. The sulfate-reducing bacteria were stained 
by the diluted Ziehl-Neeisen's carbol-fuchsin or Gram staining method after incubation for $24 \mathrm{hr}$ at $25^{\circ}$ on the TSB-plus-salts medium and their size was measured. Motility of the isolated microorganisms was examined by microscopic observation and flagella were stained by the method of Leifson.

Physiological characteristics. Carbon source utilization and other physiological tests were carried out at $25^{\circ}$ in th basal medium consisting of (per liter); $\mathrm{MgSO}_{4} \cdot 7 \mathrm{H}_{2} \mathrm{O}, 0.2 \mathrm{~g}$; $\mathrm{NaCl}, 5.0 \mathrm{~g}$; yeast extract, $2.0 \mathrm{~g}$; trypticase, $5.0 \mathrm{~g}$; phytone, $5.0 \mathrm{~g} ; \mathrm{K}_{2} \mathrm{HPO}_{4}, 2.0 \mathrm{~g}$; $\mathrm{FeSO}_{4} \cdot 7 \mathrm{H}_{2} \mathrm{O}, 2.0 \mathrm{~g}$; Na ascorbate, $0.1 \mathrm{~g} ; \mathrm{pH} 7.5$. Lactate was supplemented as the sole carbon source except in the test for acid production from carbohydrates and organic acid utilization. Production of acid from carbohydrates was examined after incubation for 7 days in a medium composed of (per liter); test carbohydrate, $5.0 \mathrm{~g}$; Bromcresol purple, $0.025 \mathrm{~g}$; basal medium, $1000 \mathrm{ml}$; pH 7.5. The carbohydrates employed were glucose, fructose, sucrose, xylose, and arabinose. Utilization of organic acids was tested after incubation by measuring turbidity of the basal medium containing $0.3 \%$ of each organic acid; lactic acid, pyruvic acid, formic acid, and lactic acid. Reduction of nitrate to nitrite was detected after incubation by the Griess-Ilosvay's reagent. Gelatinase formation was observed in the gelatin medium composed of Na-lactate $3.0 \mathrm{~g}$; gelatin, $150 \mathrm{~g}$; basal medium, $1000 \mathrm{ml}$; $\mathrm{pH}$ 7.5. Optimum growth temperature was examined by comparison of growth in the TSB-plus-salts medium at $10^{\circ}, 20^{\circ}, 30^{\circ}$, and $37^{\circ}$.

Detection of cytochromes and other pigments was performed as follows. Cultures of strain No. 64 were grown for 7 days at $25^{\circ}$ in a medium composed of $\mathrm{Na}$ lactate, $3.0 \mathrm{~g}$, in $1000 \mathrm{ml}$ of basal medium ( $\mathrm{pH} \mathrm{7.5).} \mathrm{The} \mathrm{cells} \mathrm{were}$ harvested by centrifugation, washed twice with $1 / 20 \mathrm{M}$ phosphate buffer and used for measurements. The absorption bands of the cell suspensions were recorded by spectrophotometry by Barer's procedure (5) with Shimadzu recording spectrophotometer Model MPS-50. Desulfoviridin was detected by its absorption spectrum and by the fluorescence test of POSTGATE (6).

Tolerance to sodium chloride was determined by testing the growth in the TSB-plus-salts medium supplemented with various concentrations of sodium chloride; $0,0.5,2.5,5.0$, and $10.0 \%$.

\section{RESULTS AND DISCUSSION}

Enrichment cultures made from the samples No. 61 (pond water) and No. 64 (mud) showed considerable blackening and $\mathrm{H}_{2} \mathrm{~S}$ formation in Postgate's medium and Starkey's medium at $20^{\circ}$ and $30^{\circ}$, but none at $5^{\circ}$ and $10^{\circ}$. However, as shown in Fig. 2, a large amount of iron sulfide deposited at $10^{\circ}$ when enrichment cultivation was performed for about 50 days. In the enrichment cultures obtained from sample No. 64 at $20^{\circ}$ and $30^{\circ}$, a considerable population of large rods appeared, and a few spore-forming rods were also found. On the other hand, Desulfovibrio-like bacteria were detected in the sample No. 61. These bacteria obtained from the sample No. 61 will be reported else- 
2

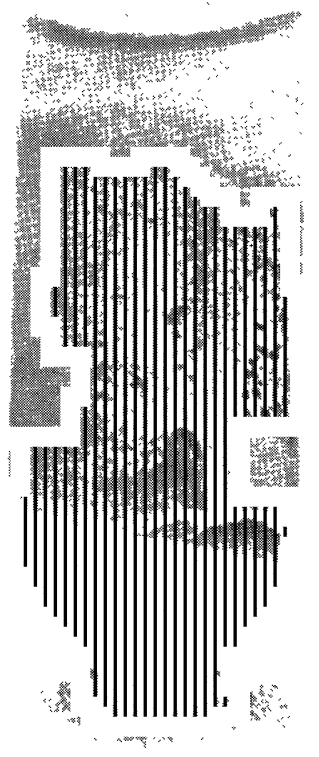

3

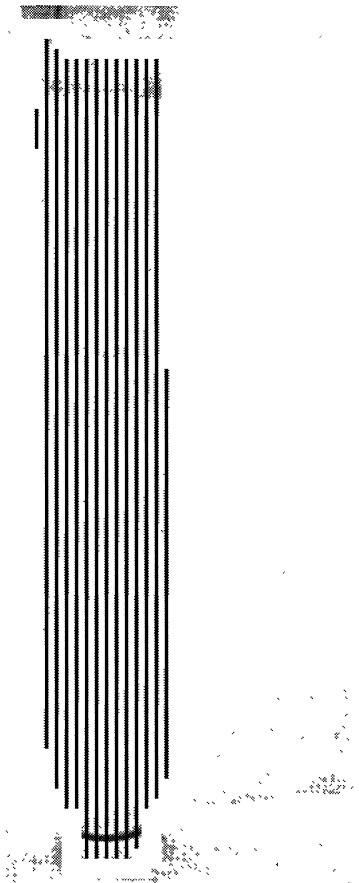

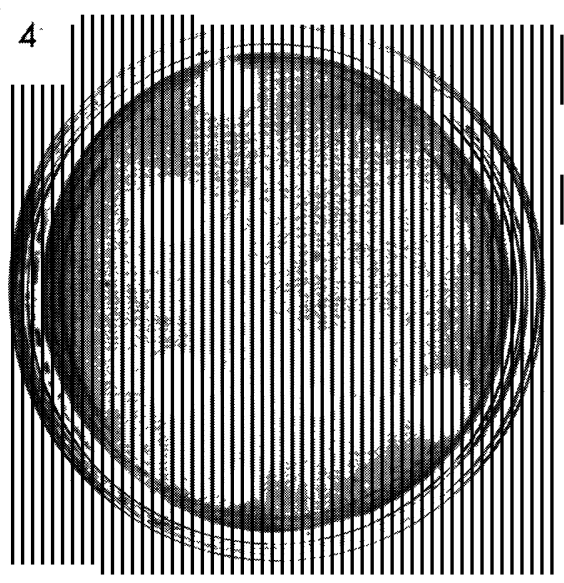

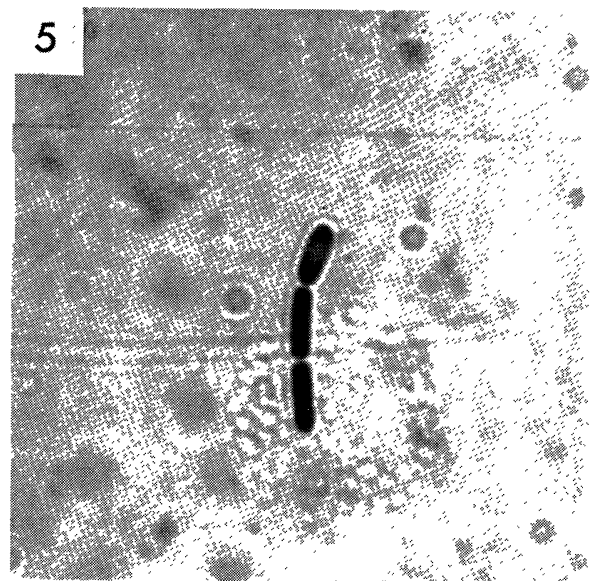

Fig. 2. Enrichment culture made from the sample No. 64 at $10^{\circ}$ for about 50 days. The black precipitate is iron sulfide.

Fig. 3. Colonies of sulfate-reducing bacterium (strain No. 64) on trypticase soy agar-plus-salts medium (TSB-plus-salts agar medium). Tube was incubated for 7 days at $30^{\circ}$ in a nitrogen atmosphere. 
where. The well-separated black colonies of spore-forming sulfate-reducing bacteria were visible after incubation for 7 days (Figs. 3 and 4) in the TSBplus-salts agar medium. Isolation by breaking the tube yielded a homogeneous culture of sulfate-reducing bacteria. The black colonies were transferred to a liquid medium and incubated at $25^{\circ}$ to check their purity. No aerobes were detected by plating out on the TSB-plus-salts agar medium and no anaerobes apart from sulfate-reducing bacteria were detected in deep agar. Fig. 5 is the isolated sulfate-reducing bacteria (strain No. 64). As seen in this photograph, the microorganism was a fat rod, sometimes paired or in short chains; mean dimension, $1-1.2$ by $4-6 \mu$. The microorganisms were Gram negative and non-progressive 'twisting and turning' motion by peritrichous flagella was observed. Spores were oval, central or terminal, slightly swelling the cells.

We did not detect a clear cytochrome band in heavy suspensions of the strain No. 64. As shown in Fig. 7, an absorption band at $553-555 \mathrm{~m} \mu$ characteristics of pyridine protohemochrome was observed after treating with $1 \mathrm{~N}$ $\mathrm{NaOH}$ and adding pyridine and $\mathrm{Na}_{2} \mathrm{~S}_{2} \mathrm{O}_{4}$. No absorption bands were observed

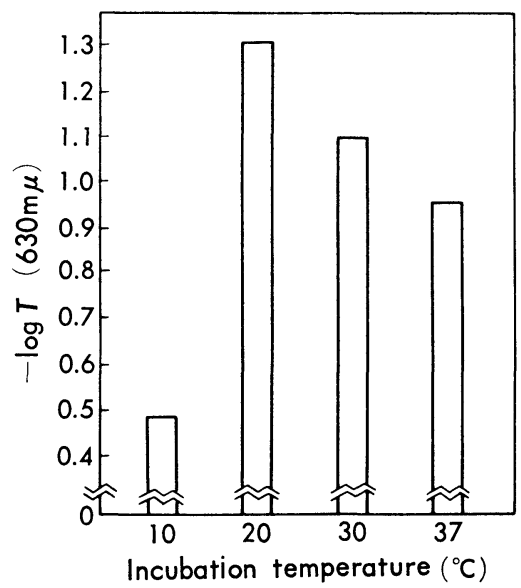

Fig. 6. Optimum growth temperature of sulfatereducing bacterium (strain No. 64) in trypticase soy broth-plus-salt medium.

Fig. 4. Plate of trypticase soy agar-plus-salts medium (TSB-plus-salts agar medium) inoculated with sulfate-reducing bacterium (strain No. 64) after 14 days of incubation at $30^{\circ}$ in a nitrogen atmosphere.

Fig. 5. Photomicrograph of sulfate-reducing bacteria (strain No. 64). Microorganisms were stained by dilute carbol-fuchsin solution. $(\times 2000)$. 


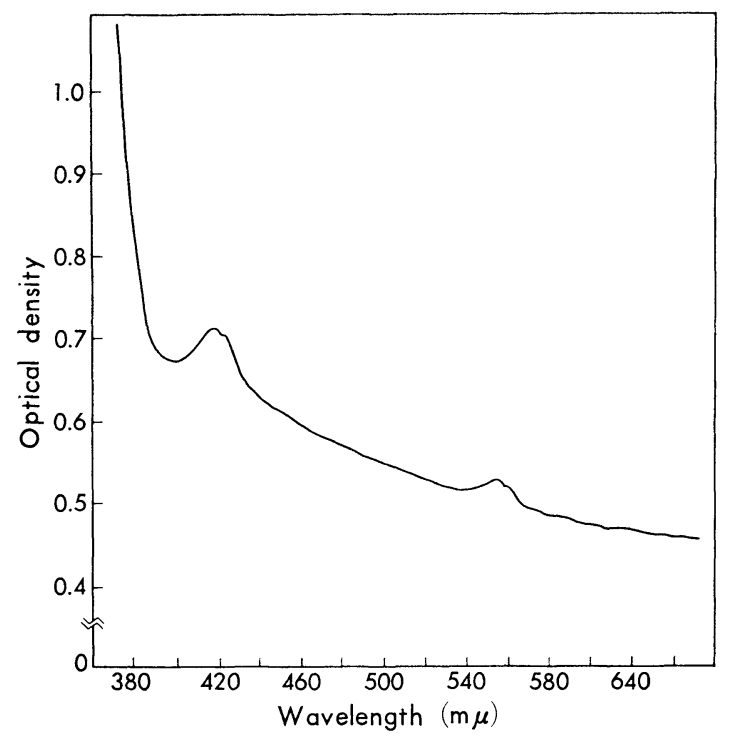

Fig. 7. Absorption spectrum of strain No. 64. Intact cells were suspended in bovine serum albumin and recorded by spectrophotometer.

at $630 \mathrm{~m} \mu$ and no fluorescent red color was detected when suspension of the strain No. 64 was treated with $\mathrm{NaOH}$ and exposed to light of $365 \mathrm{~m} \mu$. From these results it is considered that cells of the strain No. 64 contain the $b$-type cytochrome, but does not contain desulfoviridin, characteristics of the genus Desulfovibrio. CAMPBell and Postgate (4) showed that cytochrome $c$ and desulfoviridin were absent from the cells of Desulfotomaculum, but the insoluble protohem-based cytochrome, cyrochrome of the $b$ type, was present in them.

Accordingly, this strain does not belong to the genus Desulfovibrio, but does to the genus Desulfotomaculum which was proposed by CAMPBELL and Postgate (4). However, in respect to some physiological characteristics, the strain No. 64 was different from all of the known species of the genus Desulfotomaculum; D. nigrificans, D. ruminis, and $D$. orientis. Acid was produced from glucose, but not from fructose, sucrose, xylose, and arabinose. Gelatinase formation was observed after incubation for 5 days. In the description by CAMPBell and Postgate (4), three species of the genus $D e-$ sulfotomaculum were characterized by no fermentation of glucose and other carbohydrates and no liquefaction of gelatin.

Optimum temperature was examined by measuring the turbidity of culture broth at $660 \mathrm{~m} \mu$. As shown in Fig. 6, optimum temperature for the growth was $20-30^{\circ}$. It is of interest that the optimum temperature for the 
strain No. 64 is lower than those of the known three species of the genus Desulfotomaculum. Furthermore, attempts to grow this purified sulfate-reducing bacteria on Postgate's medium, Baars's medium supplemented with yeast extract ( $1 \mathrm{~g} /$ liter), medium C of Butlin, Adams, and Thomas, or Starkey's medium have resulted in poor growth. However, when these media were supplemented with increasing amount of yeast extract, peptone, trypticase, phytone, or mixtures of these organic materials, the microorganisms grew regularly. As mentioned above, growth of the strain No. 64 was observed in Postgate's medium or Starkey's medium when they were contaminated with certain other microorganisms in the sample. Accordingly, it may be assumed that the strain No. 64 is nutritionally more complex than the known species of sulfate-reducing bacteria, and, in the enrichment cultures on Postgate's medium or Starkey's medium, the contaminants in the sample supply some factors possessing a stimulating activity for the growth of strain No. 64. Further investigations on DNA base composition are in progress.

From these results, the strain No. 64 is considered as taxonomically different from all of the known species of the genus Desulfotomaculum, and is identified as a new species.

\section{DESCRIPTION OF SPECIES}

Desulfotomaculum antarcticum IIzUKA et OKAZAKI nov. sp.

Type strain: No. 64. (Fig. 5)

Fat rods, sometimes paired or in short chains, $1.0-1.2$ by $4-6 \mu$, rounded ends. Spore oval, central or terminal, slightly swelling the cells. Motile with non-progressive 'twisting and turning' motion, peritrichous flagella. Gram negative. Obligate anaerobe. Optimum temperature range $20-30^{\circ}$. Poor growth on Postgate's medium, Baars's medium supplemented with yeast ex$\operatorname{tract}(1 \mathrm{~g} /$ liter $)$, medium C of Butlin, Adams, and Thomas, or Starkey's medium. Reduces sulfate to sulfide. Nitrate not reduced. Utilizes lactate and pyruvate, but not formate or acetate. Cytochrome of the $b$ type is present. Desulfoviridin is absent. Acid from glucose, no acid from fructose, sucrose, arabinose, and xylose. Gelatin hydrolysed. Sodium chloride requirement negative. Torelance to sodium chloride: Growth at $2.5 \%$, growth scanty at $5 \%$, and no growth at $10 \%$. Forms black colonies in agar medium containing ferrous salts. Isolated from mud sample collected by Y. Honkawa from the SKARVS NES district $\left(69^{\circ} 30^{\prime} \mathrm{S}, 39^{\circ} 40^{\prime} \mathrm{E}\right)$ in the East Antarctica.

Type strain No. 64 was deposited in The IAM Culture Collection, The Institute of Applied Microbiology, University of Tokyo, Japan, in 1967.

\section{REFERENCES}

1) E.S. BARGHOORN and R.L. Nichols, Science, 134, 190 (1961).

E.S. BARGHOORN and R.L. Nichols, In Biogeography and Ecology in Antarctica, ed. 
by J. van Mieghem and P. van OYe, Dr. W. Junk Publishers-The Hague (1965), p. 276.

2) J. Postgate, In Anreicherungskultur und Mutantenauslese, ed. by H.G. Schlegel, Gustav Fischer Verlag. Stuttgart (1965), p. 190.

3) W.R. Iverson, J. Bacteriol., 14, 529 (1966).

4) L.L. Campbell and J.R. Postgate, Bacteriol. Rev., 29, 359 (1965).

5) R. BARER, Science, 121709 (1955).

6) J.R. Postgate, Nature, 183481 (1959). 